\title{
Public and corporate human resources management programs as one of the factors of monocities modernization in the framework of sustainable development
}

\author{
L.A. Chikatueva*, and T.A. Okhotina \\ Rostov State University of Economics (RINH), Rostov-on-Don, Russia
}

\begin{abstract}
In this article, the author examines the reasons for social stratification of the country's regions and singles out the difficult socioeconomic situation of the majority of single-industry municipalities in Russia as one of the main ones. The aim of the study is to analyze the efficiency of use of human resources in the country as a whole, as well as the current state of single-industry towns and create a step-by-step plan for their modernization and restructuring as a necessary vector for sustainable economic development. The article emphasizes the need to integrate efforts on the part of the state, society and business in solving social problems in certain territories. The study was carried out using the following methods: observation, modeling, method of scientific abstraction, analysis and synthesis. The study result was development of a universal step-by-step plan for development of single-industry municipalities, substantiation of the possibility of its application as one of the factors for the effective use of human resources in a particular territory.
\end{abstract}

\section{Introduction}

In September 2015, the UN General Assembly adopted the resolution "Transforming our World: the Agenda for Sustainable Development up to 2030". The document is a definite plan of action for the countries of the UN aimed at eliminating poverty, hunger, social and gender inequality, as well as environmental problems for the period up to 2030. If we consider the sustainable development goals outlined in this resolution, then at least seven out of seventeen are in one way or another related to development and improvement of human resource management [1]. This means that most of the problems that exist today as obstacles to the sustainable development of individual countries and the world economy as a whole can be solved via the more rational use of human potential.

The prerequisites of the study described above determined its goal - to analyze the efficiency of human resources use, as well as the current state of monocities in our country and creation of the staged plan for their modernization and restructuring, as a necessary vector of sustainable economic development. Relevance of the study is due to the need to

\footnotetext{
*Corresponding author: 1_chikatueva@mail.ru
} 
develop new ways to more efficiently human resources use in depressed regions of the country, develop the human potential of these regions, improve the quality of life of the population in the territory of single-industry municipalities. The offered staged plan for modernizing the economy of monocities is of practical importance, since it can be used by any municipality adjusted for the specifics of the particular region. In general, the scheme can be used at a separate enterprise to attract social investment, including in human capital. As a hypothesis, we assume the following: gradual modernization and restructuring of singleindustry municipalities in depressed regions will smooth out social stratification between individual territories of the country, as a result, make investments in human resources in all regions more profitable and improve the quality of life of the population.

\section{Study theory and methodology}

At the moment, our country is significantly inferior to many developed European countries in implementation of social policy, both at the state and corporate levels. So, for example, according to the Human Development Index (HDI) that characterizes the quality and standard of human life in the country, according to the rating compiled annually by the UN, Russia took only the 52nd place in 2019. This index is calculated considering three main directions of the country's development: health, education and GDP per capita. Let us analyze the quantitative HDI values taken from the annual final reports of the United Nations Development Program (UNDP) for the last three years using the example of 12 countries, including Russia (Figure 1).

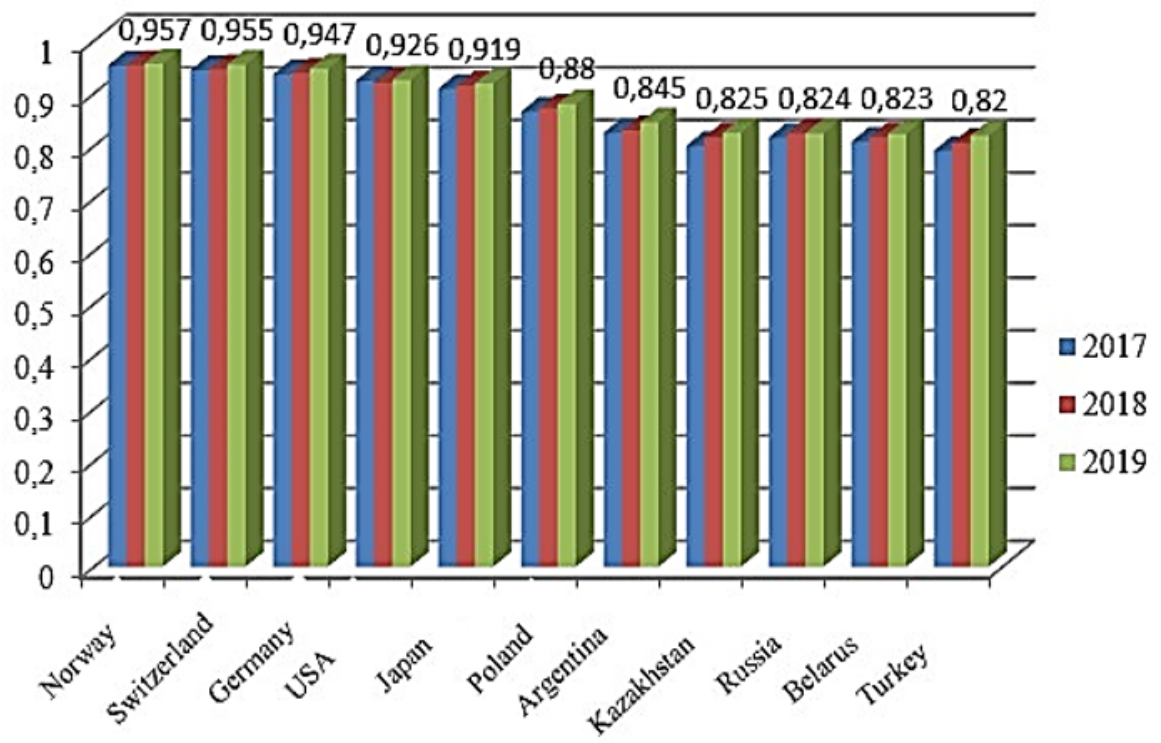

* Drawn up by the author

Fig. 1. HDI values in different countries for 2017-2019.

The figure shows that Norway is the undisputed leader in this indicator, in 2019 the HDI there was 0.957 , with the maximum possible value of 1 . Russia is ranked between its closest neighbors in the Commonwealth of Independent States Kazakhstan and Belarus, with an indicator of 0.824, yielding not only to developed European countries, the USA, Japan, but also to countries such as Poland and Argentina. The UN divides all countries by HDI into 4 
groups: countries with a very high level of this indicator, countries with a high level, with an average and low level, while our country belongs to countries with a high HDI. It is worth noting that a year ago Russia was ranked 49th in the ranking, but in 2019 we were outstripped by such countries as Kazakhstan, Palau and Romania. It is quite obvious that despite implementation of national projects as provided for in the May decree of the President of the Russian Federation V.V. Putin "On the National Goals and Strategic Objectives of Development of the Russian Federation for the Period up to 2024" development goals (increasing life expectancy, increasing real incomes, increasing pensions, improving housing conditions, reducing poverty, and etc.), our country needs cardinal changes in the area of using human potential and investing in it. The volumes and quality of investments in human resources directly affect the standard of living of the population, at the same time, according to foreign scientists, an increase in human potential by $1 \%$ leads to an acceleration of the country's GDP growth by $1-2 \%$ [2].

Solution to the problem of effective investment in human capital and creation of prerequisites for the sustainable development of the economy of our country is complicated by a number of economic, social and geopolitical factors, the key ones of which are presence of a large territory and a significant number of entities that differ in the level and quality of life of the population.

In terms of regional inequality, our country is in the third place in the world, behind Venezuela and Thailand only. The per capita income in the richest region of the country - the Yamalo-Nenets Autonomous Okrug, according to Rosstat data for the 3rd quarter of 2020 was 82,749 rubles, and the lowest average per capita income in the same period was observed in the Republic of Tyva - 15,608 rubles [3]. The difference of more than 5 times clearly indicates that serious reforms are necessary on a national scale in order to overcome the existing problems and avoid social "outbursts" and unrest in the future. Wherein, even within the federal districts, there is a colossal gap between the most successful and the poorest regions. For example, in the Urals Federal District, the difference in the level of per capita income between the Yamalo-Nenets Autonomous District and the Kurgan Region amounted to 61,784 rubles in 2019, i.e. almost 4 times (Figure 2) [4]. 


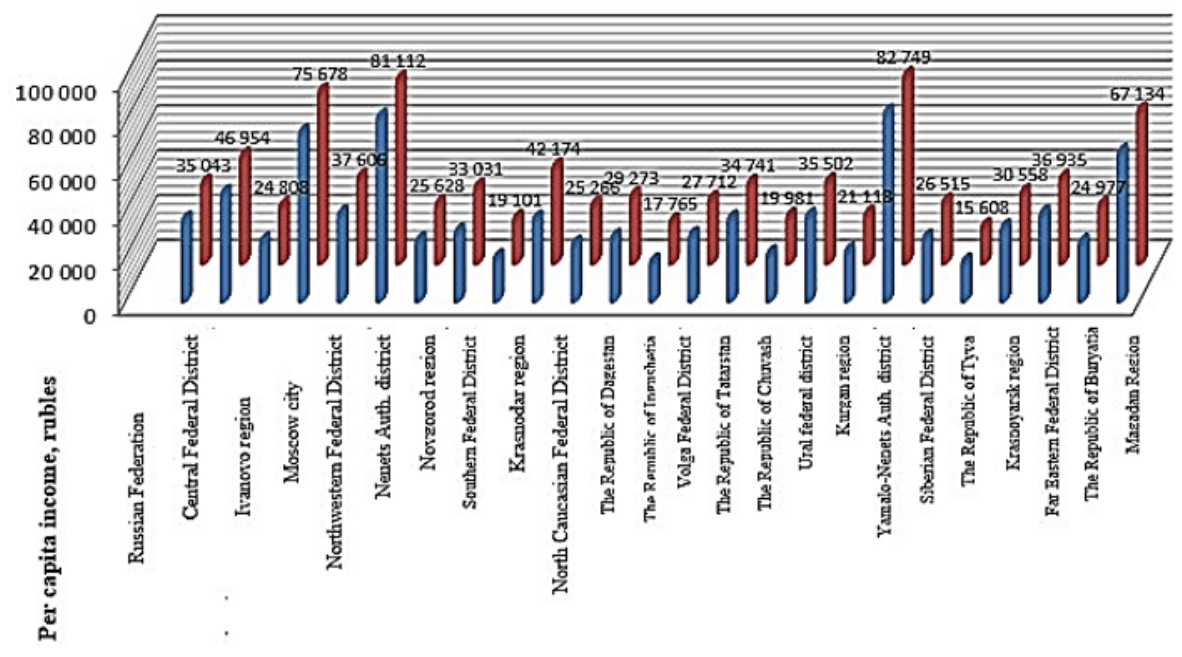

Federal districts, regions

घ 2019 year

प 2020 year (3 quarter)

* Drawn up by the author

Fig. 2. Average per capita monetary income of the population by the constituent entities of the Russian Federation (the richest and poorest region of the constituent entity), rubles/month.

The main reason for this inequality is the high concentration of industrial production in the most developed regions. Yamalo-Nenets Autonomous Okrug, Khanty-Mansi Autonomous Okrug and Moscow give the federal budget 45-50\% of all tax revenues.

On the other hand, we see depressed regions, which, even considering the state subsidies to the regional budget, fail to reduce the social gap with the richest entities by more than 3 times. Often the reason for this is the geographic location of the region, the availability of resources and their current demand on the market. Therefore, most regions with low indicators in terms of per capita income, GRP, etc. are located in the Urals and Siberia [5]. Cities here arose around industrial enterprises for the extraction or processing of minerals. Presence of a large number of such monocities, i.e. settlements founded at the city-forming enterprise, "pulls" down the economy of the region as a whole. Therefore, one of the possible options for smoothing social inequality between the regions of the country is diversification of production and the restructuring of the economies of monocities. The need to hold such events arose not so long ago, since the problems of monocities became especially acute within the economic crisis of 2007-2008. In 2010, the Government of the Russian Federation created a working group, the purpose of which was to develop a plan for financing the singleindustry municipalities. However, the offers to subsidize these settlements did not help to solve all the problems, a significant part of which lies not only in the financial plane.

Therefore, income inequality across the regions of the country is due to the different level of development of single-industry cities in these regions, while issue of universal strategies for development of these municipalities has received insufficient coverage in the currently existing studies. 


\section{Study results and their discussion}

As of January 21, 2020, there are 334 single-industry municipalities in Russia, with a total population of more than 16 million people that is more than $10 \%$ of the population of the entire country [6]. According to the current decree of the Government of the Russian Federation of July 29, 2014 No. 709, all monocities are divided into 3 categories depending on the risk of deterioration of their socio-economic situation.

The 1st category includes single-industry municipalities with the most difficult economic and social situation (these are 97 monocities, such as, for example, the city of Pervouralsk in the Sverdlovsk region, the city of Karabash in the Chelyabinsk region, and etc.). The second category includes monocities in which there are risks of deterioration of the socio-economic situation (these are 150 monocities, including Yarovoye, Altai Territory, Tynda, Amur Region, Novodvinsk, Arkhangelsk Region, and etc.). The third category includes monocities with the stable socio-economic situation. There are currently about 87 of them (for example, the city of Rossosh, the Voronezh Region, the city of Novokuznetsk, the Kemerovo Region, the city of Pechora, the Pskov Region, and etc.).

This division into categories was not accidental. Each of them requires its own approaches to solving major social and economic problems. Based on world experience, it is necessary to work out certain strategies for development of monocities, based on their economic situation at this stage.

Almost all industrially developed countries faced the problem of single-industry cities and settlements, but in most of them this problem arose much earlier than in our country, approximately in the 60-70s of XX century. In Russia, a rapid outflow of the population and the destruction of the infrastructure of monocities took place in the early $90 \mathrm{~s}$, immediately after the collapse of the Soviet Union. By this time, in Europe and America, various strategies have already been offered and are actively used to overcome the economic degradation of single-industry municipalities (for example, the experience of the Ruhr region of Germany) [7]. All these strategies can essentially be reduced to two scenarios: closure and reorganization.

The first option does not solve social problems, but only creates new ones and, moreover, the monocities that remain at the moment are too large to be completely settled apart. Closure of monocities and the resettlement of residents apart can only be used as an extreme measure, for example, in areas with unfavorable environmental conditions or too harsh climatic conditions, since presence of unpopulated areas is fraught with not only social, but also geopolitical threats [8].

The second option is the reorganization of monocities that is the most rational and acceptable for our country. In foreign practice, three strategies have been developed for implementing the rehabilitation scenario: "controlled compression", "stable monocity" and "industrial diversification".

In order to put the first strategy into practice in our country - "controlled compression", which implies a gradual controlled reduction in the population and size of the city, it is necessary to identify a group of monocities that could be "compressed". These are the largest cities from the 1 st most problematic category, having numerous economic and social problems, the solution of which on the existing scale of the municipality will be extremely unprofitable. A city-forming enterprise remains in the city, to which, if necessary, the state provides financial support, and the number of residents is brought to the required minimum based on the number of jobs at the enterprise. Therefore, the unemployment rate decreases and the social situation improves.

The "stable monocity" strategy is suitable for the 3rd most economically stable category of monocities. It implies that the city remains in the same size and with the same population, while the city-forming enterprise must operate stably, without reducing production volumes 
and the number of jobs. The municipal authorities, together with the founders of the enterprise, must provide the city and its inhabitants with the necessary social infrastructure. Enterprises that pursue a competent corporate social policy can be established with reduced rates for regional and local taxes and fees, which will be an additional incentive to participate in the social life of the city.

The third "industrial diversification" strategy is the most complex and costly. It requires an integrated development of the territory, opening the related industries by an already existing city-forming enterprise, as well as the active attraction of investors from other regions and countries. The most appropriate use of this strategy would be in single-industry municipalities belonging to the 2 nd category. To implement this strategy, you need to draw up a rough staged plan or roadmap. It can be represented in the form of a table:

Table 1. Plan of the monocities "industrial diversification" strategy implementation.

\begin{tabular}{|c|c|}
\hline Stage name & Activities \\
\hline $\begin{array}{l}\text { Stage 1. Determination of the group of } \\
\text { monocities in need of comprehensive } \\
\text { development and reorganization }\end{array}$ & $\begin{array}{l}\text { - selection of economically stable cities, but with } \\
\text { risks of worsening the situation; } \\
\text { developing the tourism industry, innovation, science and } \\
\text { education; }\end{array}$ \\
\hline $\begin{array}{l}\text { Stage 2. Drawing up a detailed city } \\
\text { development plan }\end{array}$ & $\begin{array}{l}\text { - calculation of all possible options for location } \\
\text { of various new industries; } \\
\text { - analysis of the possibility of restructuring } \\
\text { existing enterprises; } \\
\text { - selection of the most rational from an economic } \\
\text { and social point of view of options }\end{array}$ \\
\hline $\begin{array}{l}\text { Stage } 3 \text {. Determination of the circle of } \\
\text { potential investors }\end{array}$ & $\begin{array}{l}\text { - attracting investors with preferential terms for } \\
\text { loans and taxes (creation of free economic zones and } \\
\text { public-private partnerships); } \\
\text { calculation of the volume of capital } \\
\text { investments that can be attracted thanks to each of them; } \\
\text { - calculation of the amount of financial resources } \\
\text { that can be attracted at the expense of the enterprise itself }\end{array}$ \\
\hline $\begin{array}{l}\text { Stage } 4 \text {. Determination of the amount of } \\
\text { necessary state support }\end{array}$ & $\begin{array}{l}\text { - calculation of the missing amount of financial } \\
\text { resources, considering the cost of the project, possible } \\
\text { investments and the company's own resources; } \\
\text { - determining the form and type of state support } \\
\text { (soft loans, subsidies, creation of free economic zones, } \\
\text { public-private partnership) }\end{array}$ \\
\hline Stage 5: Project implementation & $\begin{array}{l}\text { - staged implementation of the measures } \\
\text { outlined in the development project; } \\
\text { control over their timely implementation; } \\
\text { of individual activities; } \\
\text { - adjustment of the development and } \\
\text { reorganization plan, if necessary; } \\
\text { arimulating the enterprise to develop various } \\
\text { areas of corporate social policy and actively participate } \\
\text { in social programs of the city }\end{array}$ \\
\hline
\end{tabular}

The plan is approximate and can be adjusted considering the certain features of specific territories. Also, in each case, it is imperative to specify the terms for each stage, to determine the responsible executors and control bodies.

Special attention shall be paid to the problem of employment of the population in singleindustry municipalities, since it is key and determines the further vector of development. 
Municipal authorities shall regularly monitor the main indicators of employment, income levels, and labor movement. Currently, social guidelines in development of the city are increasingly becoming the basis for creating development strategies, goals and missions of urban areas [9]. It is important to note here that the solution to the issue of effective use of human resources shall be carried out by joint efforts of state bodies, local governments and business structures [10]. Therefore, encouraging enterprises by the state to develop corporate social programs aimed at stabilizing the situation on the labor market by means of creating new jobs, attracting highly qualified specialists to the region, additional social packages, training programs and retraining the existing employees will allow to solve the problem of employment of the population in single-industry cities more effectively.

\section{Conclusions}

As part of implementation of the sustainable development concept, human capital acquires a special role as one of the most important factors of production. The social policy implemented today, both at the state and corporate levels, does not allow our country to even come close to those indicators of the level and quality of life that are currently demonstrated by the developed countries of the EU, the USA and Japan. One of the reasons for the lack of stable development of human resources is the difficult socio-economic situation of singleindustry municipalities, which, despite the existing development potential and the Government's attempts of "recover", are indicators of an unfavorable situation in the country's labor market. Application of the industrial diversification strategy and the offered staged plan for its implementation would allow a significant part of single-industry municipalities in our country to change the socio-economic situation for the better. This would help to reduce the unemployment rate, attract qualified personnel from more successful regions and, as a result, would lead to an increase in the level and quality of life of the population, which is a necessary prerequisite for the sustainable development of the economy of the entire country.

\section{References}

1. Transforming Our World: Transforming our World: the Agenda for Sustainable Development up to 2030. Resolution adopted by the UN General Assembly on (2015)

2. L. A. Shmeleva, K. A. Shtanova, Bulletin of the Altai Academy of Economics and Law, 11(2), 369 (2020)

3. Regions of Russia. Socio-economic indicators, 1242 (2020)

4. Regions of Russia. Socio-economic indicators, 1204 (2019)

5. T. A. Vereshchagina, K. A. Trushkina, Problems and prospects of economics and management: materials of the IV International scientific conference, 172 (2015)

6. On approval of the list of single-industry municipalities of the Russian Federation (monocities): Order of the Government of the Russian Federation of July 29, 2014 No. 1398-r

7. A. O. Sobolev, Management issues, 32, 75 (2015)

8. V. V. Fauzer, A. V. Smirnov, G. N. Fauzer, Economy of region, 17(2), 552 (2021)

9. O.V. Artemova, N. M. Logacheva, and A. N. Savchenko, Economy of region, 17(2), 538 (2021)

10. S.V. Kulay, Public Administration. Electronic Bulletin, 73, 224 (2019) 
11. T. A. Vereshchagina, Problems and prospects of economics and management: materials of the IV Mezhdunar scientific conference, 172 (2015) 